\title{
PHARMACOKINETIC STUDIES ON THE HEPATOTOXICITY OF LUTEOSKYRIN. (I) INTRACELLULAR DISTRIBUTION OF RADIOACTIVITY IN THE LIVER OF MICE ADMINISTERED ${ }^{3} \mathrm{H}$-LUTEOSKYRIN
}

\author{
Ikuko UENO. Toniko HAYASHI* and Yoshio UENO* \\ Institute of Medical Science, University of Tokvo, \\ Shirokanedai, Minato-ku, Tokyo and \\ Microbial Chemistrv*, Faculty of Pharmaceutical Sciences, \\ Tokyo University of Science. Tokyo, Japan
}

Accepted February 14, 1974

\begin{abstract}
Intracellular distribution of the radioactivity derived irom ${ }^{3} \mathrm{H}$-luteoshyrin in mouse liver was investigated. It was revealed that lutenskyrin has a high affinity to mitochondria and cell debris of mouse liver cells. This characteristic distribution pattern in the liver cells maty be responsible for the mitochondrial impairment and the age and sex differences in the susceptibility of mice to this mycotoxin.
\end{abstract}

Luteoskyrin, one of the anthraquinoid metabolites of Penicillimm islandicum Sopp, affects selectively the livers of mice and rats and causes both acute and chronic disorders including centrolobular necrosis, fatty metamorphosis, cirrhosis and hepatoma depending upon the dose and duration of administration (1-3).

In order to elucidate the processes of development of the acute injury into a chronic intoxication, the authors performed toxicological studies of the acute stage of luteoskyrin intoxication, and found that this mycotoxin exhibits varying degrees of toxicity depending on the species, strain, sex and age of experimental animals; the susceptibility of mice is higher than that of rats, and in mice it is higher in males and infants than in females and adults (4).

Pharmacokinetic studies with ${ }^{3} \mathrm{H}$-luteoskyrin (5) showed that the hepatotoxicity in mice is ascribable to the selective concentration of the mycotoxin in the liver. Biochemical investigations revealed further that lutenskyrin acts as an inhibitor of the respiratory enzyme system (6) and the coupled phosphorylation (7) of liver mitochondria, and binds to DNA (8 10) with resultant suppression of RNA synthesis (11).

In an attempt to confirm the possibility that luteoskyrin or its metabolites directly attack the cellular components of the liver to cause the above mentioned biochemicat atterations in the course of the intoxication, intracellular distribution of the radioactivity derived from ${ }^{3} \mathrm{H}$-Juteoskyrin in the liver of mice of different ages and sexes was examined. It was found that the large portion of the tritium label taken up by the liver was distribut-

This work was presented at the 45th General Meeting of Japanese Pharmacological Society, Sendai, Japan, Apr. 27-29, 1972 (Japan. J. Pharmacol. 22, Supplementum 115, 1972),

Supported in part by the Cancer Research Grant from the Ministry of Welfare, 
ed in the fractions of mitochondria and cell debris and the content in these fractions was higher in male and suckling mice than in female and adult animals in accordance with the differences in their susceptibility to this mycotoxin.

\section{MATERIALS AND METHODS}

DDD-strain mice bread in the laboratory of Tokyo University of Scicnce were used in all the experiments. Adult animals were housed in groups of two per cage and each group was given $9 \mathrm{~g}$ of commercial pellets (CE-2, Nihon Clea Ltd.) a day and water ad libitum. Sucklings at 2-weeks-old were housed in a cage with their dam.

\section{${ }^{3}$ H-lutcoshyrin}

Luteoskyrin (LS) was extracted from the fungus mat of $P$. islandicum Sopp and purified by Tatsuno's method modified by Leno and Ishikawa (12), and ${ }^{3} \mathrm{H}$-labelling of LS was kindly conducted by Dr. T. Komai (National Institute of Health. Tokyo, Japan). Specific radioactivities of the labelled compound are given under the table for each experiment. Administration of ${ }^{3} \mathrm{H}-\mathrm{LSS}$ and proparation of the subcellular firactions

${ }^{3} \mathrm{H}$-LS suspended in olive oil was injected s.c. into the mice. Under ether anesthetic, about $500 \mathrm{mg}$ of the liver was excised and chilled in ice cold saline. The chilled liver tissue was weighed and homogenized in $0.25 \mathrm{M}$ sucrose to make a $10 \%$ " homogenate. The homogenate was centrifuged at $2,500 \mathrm{kpm}$ for $10 \mathrm{~min}$ twice, $6,500 \% \mathrm{~g}$ for $10 \mathrm{~min}$ twice, $15,000 \times \mathrm{g}$ for $10 \mathrm{~min}$, and $105,000 \mathrm{~g}$ for $60 \mathrm{~min}$ to separate mitochondrial, light mitochondrial, microsomal and supernatant fractions, respectively. The remaining liver was perfused in situ via the portal vein with ice cold $0.25 \mathrm{M}$ sucrose containing $3.3 \mathrm{mM} \mathrm{CaCl} 2$ and then removed. The perfused liver was homogenized in twelve volumes of $2.2 \mathrm{M}$ sucrose containing $3.3 \mathrm{mM} \mathrm{CaCl}_{2}$ in a Potter-Elvehjen type glass homogenizer. The homogenate was filtered through four layers of guaze and centrifuged at $40,000 \times \mathrm{g}$ for 90 min in a Hitachi 65P preparative ultracentrifuge. The pellet obtained was suspended in $0.34 \mathrm{M}$ sucrose and centrifuged at $2,000 \mathrm{rpm}$ for 10 min. This pellet was then used as the nuclear fraction.

Measurement of radioactivity

Each fraction was suspended in water and 0.1 to $0.3 \mathrm{ml}$ of the suspension was pipetted into at vial. After $0.1 \mathrm{ml}$ of Hyamine was added to solubilize the sample, $10 \mathrm{ml}$ of the ANPO solution (naphthalene $73.9 \mathrm{~g}, 2.5$-diphenyloxazole $4.6 \mathrm{~g}, 2-(1$-naphtyl)-5-phenyloxazole $0.46 \mathrm{~g}$. xylene $350 \mathrm{ml}$, dioxane $350 \mathrm{ml}$, ethanol $210 \mathrm{ml}$ ) was added and the radioactivity was counted with a Beckman LS 200 type liquid scintillation counter.

The protein content of each fraction was assayed by the methods of Biuret and Lowry (13).

\section{RESULTS}

\section{Adult mal' mice'}

Radioactivities detected in the homogenate and subcellular fractions of the livers of male mice injected s.c. with ${ }^{3} / 1-L S$ are shown in Table 1 . Radioactivities recovered from the li- 
TABLE 1. Intracellular distribution of radioactivity in the livers of male mice subcutaneously injected with ${ }^{3} \mathrm{H}$-LS

\begin{tabular}{|c|c|c|c|c|c|c|c|c|c|c|}
\hline \multirow{3}{*}{$\begin{array}{c}\text { Time } \\
\text { after } \\
{ }^{3} \mathrm{H}-\mathrm{LS} \\
\text { injection }\end{array}$} & \multirow{3}{*}{$\begin{array}{l}\text { No. } \\
\text { of } \\
\text { mice }\end{array}$} & \multicolumn{9}{|c|}{ Radioactivity in liver } \\
\hline & & \multicolumn{7}{|c|}{$\left(\times 10^{3} \mathrm{dpm} / \mathrm{g}\right)$} & \multirow{2}{*}{$\begin{array}{c}\% \text { of } \\
\text { the } \\
\text { injected } \\
\text { dose }\end{array}$} & \multirow{2}{*}{$\begin{array}{c}\mathrm{LS} \\
\text { content } \\
(\mu \mathrm{g} / \mathrm{g})\end{array}$} \\
\hline & & Homogenate & Nuclei & $\begin{array}{c}\text { Mito- } \\
\text { chondria }\end{array}$ & $\begin{array}{l}\text { Light } \\
\text { mito- } \\
\text { chondria }\end{array}$ & $\begin{array}{l}\text { Micro- } \\
\text { somes }\end{array}$ & $\begin{array}{l}\text { Super- } \\
\text { natant }\end{array}$ & $\begin{array}{c}\text { Cell } \\
\text { debris }\end{array}$ & & \\
\hline \multirow[t]{4}{*}{$15 \mathrm{hr}$} & 1 & 752.2 & 3.9 & 351.6 & 34.6 & 34.8 & 39.2 & 328,0 & 1.74 & 26 \\
\hline & 2 & 589.5 & 0.6 & 257.0 & 28.7 & 22.2 & 36.6 & 245.0 & 1.64 & 21 \\
\hline & 3 & 528.0 & 1.4 & 230.0 & 22.5 & 23.6 & 43.9 & 208.0 & 1.38 & 18 \\
\hline & $(\mathbf{M})$ & 623.2 & 2.0 & 279.5 & 28.6 & 26.9 & 39.9 & 260.3 & 1.59 & 22 \\
\hline \multirow[t]{4}{*}{$23 \mathrm{hr}$} & 1 & 815.6 & 1.4 & 413.7 & 33.0 & 21.4 & 53.3 & 318.3 & 1.82 & 28 \\
\hline & 2 & 774.7 & 0.3 & 407.9 & 23.0 & 12.8 & 57.0 & 278.2 & 1.67 & 27 \\
\hline & 3 & $1,704.4$ & 15.3 & 779.5 & 87.9 & 49.0 & 85.4 & 584.0 & 3.64 & 59 \\
\hline & $(\mathrm{M})$ & $1,098.2$ & 5.7 & 533.7 & 48.0 & 27.7 & 65.2 & 393.5 & 2.38 & 38 \\
\hline \multirow[t]{3}{*}{1 week } & 1 & 413.5 & 2.7 & 149.5 & 21.9 & 29.0 & 49.5 & 109.5 & 1.33 & 14 \\
\hline & 2 & 255.5 & 2.1 & 87.9 & 9.2 & 9.2 & 41.9 & 92.3 & 0.82 & 9 \\
\hline & $(\mathrm{M})$ & 334.5 & 2.4 & 118.7 & 15.6 & 19.1 & 45.7 & 100.9 & 1.08 & 12 \\
\hline
\end{tabular}

$2.25 \mathrm{mg} / 0.3 \mathrm{ml} / \mathrm{A}$ of ${ }^{3} \mathrm{H}-\mathrm{LS}$ (Sp. Act. $2.88 \times 10^{4} \mathrm{dpm} / \mathrm{g}$ ) suspended in olive oil were injected s.c. into DDD male mice (10-weeks). M : Mean value.

vers were $1.59^{\prime \prime}$ and $2.38^{\prime \prime}$ "of the total dose administered $15 \mathrm{hr}$ and $23 \mathrm{hr}$ after the injection, respectively. Though the maximum radioactivity detected in the liver was only about $2 \%$ of the dose, $1.08 \%$ of the dose, corresponding to a half of the maximal level, remained even one week after the injection.

Assuming that all the rattionctivitice counted were "ll-L.S. the content of L.S was $38 / 2 \mathrm{~g}$ per of wet liver at the maximum and 12 feg one week afler the athministration.

Among the subcelluar fractions the mitochondrial fraction had the highest radioattivities representing 40 to $50 \%$ of the total liver radioactivity. Thirty to $40 \%$ of the liver radioactivity was recovered from the cell debris fraction. The microsomal fraction contained only 2 to $6 \%$ of the liver radioactivity. The percent radioactivity of the supernatant fraction increased with time atler the injection (Table 2).

The specific radioactivity per me protein calculated from the above data and the protein content is shown in Table 3. The highest specific radioactivity was seen in the mitochondrial fraction followed by the cell debris, nuclear and light mitochondrial fractions.

TABLE 2. Percent radioactivities in the subcellular fractions of the livers of male mice subcutaneously injected with ${ }^{3} \mathrm{H}-\mathrm{LS}$

\begin{tabular}{cccccc}
\hline $\begin{array}{c}\text { Time after } \\
{ }^{3} \text { H-LS injection }\end{array}$ & Mituchondria & $\begin{array}{c}\text { Light } \\
\text { mitochondria }\end{array}$ & Microsomes & Supernatant & Cell debris \\
$15 \mathrm{hr}$ & 43.1 & 4.6 & 4.3 & 6.6 & 41.5 \\
$23 \mathrm{hr}$ & 50.5 & 4.1 & 2.4 & 8.5 & 36.5 \\
1 week & 40.1 & 5.0 & 5.9 & 15.5 & 34.0 \\
\hline
\end{tabular}

Calculated from the mean values in Table 1 . 
Tabu. 3. Specific radicactivitic of the subcellular frations of the livers of malc mice subcutaneously injected with ${ }^{3} \mathrm{H}$-LS

\begin{tabular}{ccccccc}
$\begin{array}{c}\text { Time after } \\
\text { "H-LS injection }\end{array}$ & \multicolumn{5}{c}{ Specific radioactivity } & dom/mg protein) \\
& Nuclei & Mitochondria & $\begin{array}{c}\text { Light } \\
\text { mitochondria }\end{array}$ & Microsomes & Supernatant & Cell debris \\
$15 \mathrm{hr}$ & 1645 & 5298 & 1132 & 780 & 278 & 1898 \\
$23 \mathrm{hr}$ & 605 & 6027 & 737 & 1185 & 165 & 752 \\
1 week & 832 & 3553 & 830 & 488 & 315 & 793 \\
\hline
\end{tabular}

Calculated from the values in Table 1 and the protein contents.

The supernatant fraction showed lowest radioactivities, about one tenth to one fortieth that observed in the mitochondrial fraction.

The specific radioactivity in the mitochondrial fraction was highest at $23 \mathrm{hr}$ after the administration and decreased to a half after one week, although it was still higher than those of the other fractions. The highest specilic radioactivity of the nuclear fraction was seen at $15 \mathrm{hr}$ after the injection. I1 corresponded to one third that of the mitochondral fraction measured at the same time.

Adult fermale mice

The intracellular distribution of radioactivity in the livers of adult female mice is shown in Table 4. The amoun of radioacivity in the livers taken $15 \mathrm{hr}$ and $23 \mathrm{hr}$ after the injection was $0.80 \%$ and $0.78 \%$, respectively, of the total dose administered. It decreased to $0.20 \%$ one week after the injection. The distribution pattern in the fentale mice differed

TABвt. 4. Intracellular distribution of radioactivity in the livers of female mice subcutancously injecled with ${ }^{3} \mathrm{H}$-LS.

\begin{tabular}{|c|c|c|c|c|c|c|c|c|c|c|}
\hline \multirow{3}{*}{$\begin{array}{c}\text { Time } \\
\text { after } \\
{ }^{3} \mathrm{H}-\mathrm{LS} \\
\text { injection }\end{array}$} & \multirow{3}{*}{$\begin{array}{l}\text { No. } \\
\text { of } \\
\text { mice }\end{array}$} & \multicolumn{9}{|c|}{ Radioactivity in liver } \\
\hline & & \multicolumn{7}{|c|}{$\left(\times 10^{3} \mathrm{dpm} / \mathrm{g}\right)$} & \multirow{2}{*}{$\begin{array}{c}\text { the } \\
\text { injected } \\
\text { dose }\end{array}$} & \multirow{2}{*}{$\begin{array}{c}\text { LS } \\
\text { conten } \\
(\because \mathrm{g} / \mathrm{g})\end{array}$} \\
\hline & & Homogenate & Nuclei & $\begin{array}{l}\text { Mito- } \\
\text { chondria }\end{array}$ & $\begin{array}{c}\text { Light } \\
\text { mito- } \\
\text { chondria }\end{array}$ & $\begin{array}{l}\text { Micro- } \\
\text { somes }\end{array}$ & $\begin{array}{l}\text { Super- } \\
\text { natant }\end{array}$ & $\begin{array}{l}\text { Cell } \\
\text { debris }\end{array}$ & & \\
\hline \multirow[t]{4}{*}{$15 \mathrm{hr}$} & 1 & 341.3 & 1.1 & 78.5 & 13.4 & 35.9 & 78.5 & 135.0 & 0.95 & 12 \\
\hline & 2 & 314.5 & 2.0 & 71.5 & 13.7 & 33.7 & 80.6 & 115.0 & 0.82 & 11 \\
\hline & 3 & 205.6 & 0.7 & +2.0 & 13.1 & 17.8 & 51.2 & 81.5 & 0.62 & 7 \\
\hline & $\mathrm{M})$ & 287.1 & 1.3 & 64.0 & 13.4 & 29.1 & 70.1 & 110.5 & 0.80 & 10 \\
\hline \multirow[t]{4}{*}{$23 \mathrm{hr}$} & 1 & 385.8 & 3.3 & 138.8 & 16.1 & 20.0 & 105.1 & 101.7 & 0.81 & 13 \\
\hline & 2 & 517.8 & 0.5 & 203.0 & 14.3 & 17.8 & 99.6 & 215.3 & 1.19 & 18 \\
\hline & 3 & 176.6 & 0.5 & 41.3 & 6.3 & 11.4 & 68.3 & 75.3 & 0.33 & 6 \\
\hline & (M) & 359.9 & 1.4 & 127.7 & 12.2 & 16.4 & 91.0 & 130.9 & 0.78 & 13 \\
\hline \multirow[t]{4}{*}{1 week } & 1 & 76.2 & 0 & 14.3 & 4.4 & 7.9 & 26.4 & 22.2 & 0.19 & 3 \\
\hline & 2 & 132.5 & 0 & 25.2 & 4.9 & 10.2 & +0.3 & 44.3 & 0.30 & 5 \\
\hline & 3 & 40.5 & 0 & 7.3 & 2.6 & 3.8 & 15.0 & 8.3 & 0.11 & 1 \\
\hline & $\mathrm{M})$ & 83.1 & 0 & 15.6 & 4.0 & 7.3 & 27.2 & 24.2 & 0.20 & 3 \\
\hline
\end{tabular}

$2.25 \mathrm{mg} 0.3 \mathrm{ml} / \mathrm{A}$ of ${ }^{3} \mathrm{H}-\mathrm{LS}$ (Sp. Act. $2.88 \times 10^{4} \mathrm{dpm} / \mu \mathrm{g}$ ) suspended in olive oil were injected s.c. into DDD female mice (10-weeks). M: Mean value. 
TABkI 5. Percent radioactivities in the subcellular fractions of the liver of female mice subcutaneously injected with ${ }^{3} \mathrm{H}-\mathrm{LS}$

\begin{tabular}{cccccc}
\hline $\begin{array}{c}\text { Time after } \\
{ }^{3} \mathrm{H}-\mathrm{LS} \text { injection }\end{array}$ & Mitochondria & $\begin{array}{c}\text { Light } \\
\text { mitochondria }\end{array}$ & Microsomes & Supernatant & Cell debris \\
$15 \mathrm{hr}$ & 22.0 & 4.9 & 10.0 & 24.5 & 38.6 \\
$23 \mathrm{hr}$ & 31.3 & 3.3 & 4.7 & 25.9 & 34.6 \\
1 week & 19.6 & 5.6 & 9.6 & 35.8 & 29.0 \\
\hline
\end{tabular}

Calculated from the mean values in Table 4.

TABLF 6. Specific radioactivities of the subcellular fractions of the liver of female mice subcutaneously injected with ${ }^{3} \mathrm{H}-\mathrm{LS}$

\begin{tabular}{ccccccc}
\hline $\begin{array}{c}\text { Time after } \\
{ }^{3} \mathrm{H}-\mathrm{LS} \text { injection }\end{array}$ & Suclei & Mitochondria & $\begin{array}{c}\text { Light } \\
\text { mitochondria }\end{array}$ & Microsomes & Supernatant & Cell debris \\
& 972 & 1460 & 235 & 818 & 462 & 657 \\
$23 \mathrm{hr}$ & 790 & 1428 & 323 & 817 & 238 & 258 \\
$1 \mathrm{heek}$ & 136 & 363 & 140 & 185 & 135 & 132 \\
\hline
\end{tabular}

Calculated from the values in Table 4 and the protein contents.

from that in the males: the pereent radioactivity in the mitochondrial fraction was lower in the females than in the males, whereas the radioactivity in the supernatant fraction was higher in female mice than in male mice at all times (Table 5). As shown in Table 6, highest specific radioactivities were also seen in the hepatic mitochondrial fractions of the female mice, but they were only one fourth those of the males $15 \mathrm{hr}$ and $23 \mathrm{hr}$ after the injection, respectively. The specilic radioactivity of the microsomal fraction was higher than those of the cell debris, supernatant and light mitochondrial fractions at all times.

\section{Sirckling mice}

The radioactivities of the livers from two-week-old mice injected with $0.07 \mathrm{ml}$ of ${ }^{3} \mathrm{H}-\mathrm{LS}$ solution $(71 \mu \mathrm{g} / 0.1 \mathrm{ml})$ per animal were compared with those of adult mice given $0.3 \mathrm{ml}$ of the same solution per animal. The latter dose corresponded to one tenth the dose administered to the adult mice in the previous experiments. The radioactivities in the livers of the sucklings were $1.62 \%$ in malc and $1.43 \%$ in female mice of the administered dose, and those in the adults were $0.26 \%$ in male and $0.19 \%$ in female mice (Table 7). The result indicates that, when the dose per $\mathrm{kg}$ was the same in sucklings and adults, the amount of radioactivity in the livers of the sucklings was several times higher than that of the adults. In sucklings, the percent radioactivities in the mitochondrial fractions were lower than those in the supernatant fractions. In adult mice, about $30 \%$ of the liver radioactivity was distributed in the fractions of mitochondria, supernatant and cell debris. When the specitic radioactivities in the subcellular fraction were compared between the sucklings and the aduts, the former wore up to ten times higher than the latter (Table 7). The highest specific radioactivity was seen in the mitochondrial fraction from both the sucklings and the adults (Table 7). There was no great sex difference between the sucklings and the adults (Table 7). 
TaBL: 7. Effect of age on decumulation and intracellular distribution of radioactivity in the liver of mice subcutaneously injected with ${ }^{3} \mathrm{H}-\mathrm{LS}$.

\begin{tabular}{|c|c|c|c|c|c|c|c|c|c|}
\hline \multirow{2}{*}{$\begin{array}{l}\text { Age } \\
\text { week }\end{array}$} & \multirow[t]{2}{*}{$\operatorname{Sex}$} & \multicolumn{3}{|c|}{ Radioactivity in liver } & \multicolumn{5}{|c|}{ Percent of liver radioactivity } \\
\hline & & $\left(\times 10^{3}\right.$ dpmig $)$ & $\begin{array}{c}\text { LS } \\
\text { content } \\
\mu \mathrm{g} g \mathrm{~g}\end{array}$ & $\begin{array}{c}\% \text { of } \\
\text { the } \\
\text { injected } \\
\text { dose }\end{array}$ & $\begin{array}{l}\text { Mito- } \\
\text { chondria }\end{array}$ & $\begin{array}{l}\text { Light } \\
\text { mito- } \\
\text { chondria }\end{array}$ & $\begin{array}{l}\text { Micro- } \\
\text { somes }\end{array}$ & $\begin{array}{l}\text { Super- } \\
\text { natant }\end{array}$ & $\begin{array}{c}\text { Cell } \\
\text { debris }\end{array}$ \\
\hline \multirow[t]{4}{*}{2} & Male & 149.6 & 1.2 & 1.62 & 20.3 & 6.0 & 5.1 & 32.4 & 36.2 \\
\hline & $(13)^{*}$ & & & & 820 & 590 & 240 & 447 & - \\
\hline & Female & 132.0 & 1.0 & 1.43 & 18.8 & 5.3 & 6.2 & 32.3 & 37.4 \\
\hline & (9) & & & & 660 & 390 & 202 & 306 & - \\
\hline \multirow[t]{4}{*}{10} & Male & 72.2 & 0.6 & 0.26 & 32.6 & 5.9 & 6.8 & 27.0 & 31.0 \\
\hline & $(3)$ & & & & 185 & 78 & 55 & 49 & - \\
\hline & Female & 52.8 & 0.4 & 0.19 & 26.7 & 7.2 & 8.1 & 32.7 & 25.3 \\
\hline & (3) & & & & 79 & 52 & 42 & 37 & - \\
\hline
\end{tabular}

Bold-type letters : Specific radioactivity (dpmimg protein?.

* ( ) Number of mice used.

Male and female mice of DDD strain (2 and 10 weeks) were used.

An olive oil solution of ${ }^{3} \mathrm{H}$-LS $\left(\mathrm{Sp}\right.$. Act. $\left.1.3 \times 10^{3} \mathrm{dpm} / \mu \mathrm{g}, 71 \mu \mathrm{g} / 0.1 \mathrm{ml}\right), 0.07 \mathrm{ml}$ for sucklings and $0.3 \mathrm{ml}$ for adults, was injected s.c. $15 \mathrm{hr}$ prior to sacrifice.

\section{DISCLSSION}

In agreement with the previous result (5), the low absorption of luteoskyrin in mice was also demonstrated in the present study: the highest content of the ${ }^{3} \mathrm{H}$-compounds $\left({ }^{3} \mathrm{H}\right.$ luteoskyrin and its metabolites) in the liver was $2.38^{\circ}$, of the dose in the male and $0.80^{\circ} \mathrm{u}$ in the female (Tables 1 and 4). The different percent radioactivities between the male and the female (Tables 1 and 4) or between the suckling and adult (Table 7) indicaled that the content of the alf-compounds in the liver varted with age and sex.

As revealed in the preceding experiments, the toxic effect of lutcoskyrin upon the liver was marked in the young as compared with adult mice and also more marked in the male than the female (4). From both the present and previous observations, it may be concluded that higher contents of the ${ }^{3} \mathrm{H}$-compounds are detected in the liver of animals more susceptible to this mycoloxin. Therefore, the high susceptibility of mice to the hepatotoxic mycotoxin may be attributable to the specific concentration of this mycotoxin or its metabolites in the hepatic cells.

As for the distribution of the ${ }^{3} \mathrm{H}$-compounds in the hepatic cells, a large portion of the radioactivity was detected in the mitochondrial fraction (Table 1,4 and 7). The specific radioactivity in this fraction was much higher than that in the other fractions including the microsomes and supernatint (Table 3, 6 and 7). This fact suggests that luteoskyrin or its melabolites have a high affunty to cortain mitodondral compenents. It was found that more than $80^{\circ}$, of the total radioactivity detected in the mitochondrial fraction wats derived from ${ }^{3} \mathrm{H}$-luteoskyrin itself, therefore it is most likely that the ${ }^{3} \mathrm{H}$-compounds described here correspond $10{ }^{3} \mathrm{H}$-luteoskyrin (To be published in the succeeding paper). Such being the case, lutcoskyrin itself may have a selective, high affinity to mitochondria of the liver. This high affinity of luteoskyrin to mitochondrial components was evident irre- 
spective of age and sex (Table 3, 6 and 7).

Based on the electronmicroscopic findings of the swelling of rat liver mitochondria induced by luteoskyrin $(14,15)$, the light mitochondrial fraction which may include the swollen mitochondria, was anticipated to show a high radioactivity. However, neither the total radioactivity nor the specific radioactivity was high enough to indicate a specific concentration of the ${ }^{8} \mathrm{H}$-compounds in this fraction.

According to the previous work, luteoskyrin inhibits activities of the respiratory enzyme system and the coupled phosphorylation of rat liver mitochondria in vitro. A suppression of these activities was also demonstrated in mice and rats which had been administered this mycotoxin $(6,7)$. The concentration of luteoskyrin into the mitochondrial fraction as shown in the present study supports the authors' hypothesis that luteoskyrin impairs the energy producing system of the mitochondria during the course of acute liver injury.

A large part of the liver radioactivity was found in the fraction of cell debris, and the specific radioactivity in this fraction changed in parallel with the susceptibility of mice to this mycotoxin. These findings suggest the important role of some component of the cell debris in the occurrence of the liver cell damage by this mycotoxin. Since this fraction includes the nuclei and the cell membrane, luteoskyrin may have some effect on these cellular components.

As for the effect on the nuclei, an impaiment by this mycotoxin had been demonstrated in the pathological and biochemical observations of karyorrhexis (1) and an enhanced incorporation of ${ }^{8} \mathrm{H}$-thymidine (16) in the acutely poisoned liver. The binding of luteoskyrin to DNA (8-10) and suppression of the RNA synthesis (11) in vitro were further demonstrations of the possible effect on cell nuclei. These observations suggest the high affinity of luteoskyrin to the cell nucleus. Although a relatively high specific radioactivity was obtained in the nuclear fraction, the amounts of the nuclear fraction separated in these experiments were too small for a detailed analysis. More precise experiments are now being carried out.

As for the cell membrane, an inhibitory effect of luteoskyrin on the Na-K-ATPase aclivity in vitro was observed in a previous work (17). Lutcoskyrin may also affect the cell membrane, but it is still obscure whether this large amount of the ${ }^{3} \mathrm{H}$-compounds accumulates in the cell membrane or in other parts of the cell debris.

Acknowledgements: The authors wish 10 gratefully acknowledge Professors $\mathrm{K}$. Uraguchi (Tokyo University of Agriculture) and M. Saito (Institute of Medical Science, University of Tokyo) for their advice and encouragentent.

\section{REFERENCES}

1) Uragichil, K., Tatsuio, T., Sakal, F., Tsukioka, M., Sakal, Y., Yonfmitsu, O., Ito, H., Miyake, M., Salio, M., Enomoto, M., Simkaia, T. Avd lshiko, T.: Japan. J. exp. Med. 31, 19 (1961)

2) Uraguchl, K., Saito, M., Noguchl, Y., Takahasht, K., ENomoto, M. and Tatsuno, T.: Fd Cosmet. Toxicol. 10, 193 (1972) 
3) Miraki, M., Saito, M., Evomoro, M., Silikata, T., Ishiko, T., Uraguchi, K., Sakai, F., Tatsuno, T., Tsukioka, M. and Sakal, Y.: Acta path. Japon. 10, 75 (1960)

4) Uraciuchi, K., Ufno, I., Akabori, A. and Enomoto, M.: Folia pharmacol. japon. 64, 1 (1969) (in fapanese)

5) Uraglchi, K., Uexo, I., Uexo, Y. avd Komat, T.: Toxic. appl. Pharmacol. 21, 335 (1972)

6) Ueno, I., Ueno, Y., Tatsuno, T. and Uraguchi, K.: Japan. J. exp. Med. 34, 135 (1964)

7) Ueno, I.: Seikagaku 38, 741 (1966) (in Japanese)

8) Uleno, Y., Platel, A. and Fromageot, P.: Biochim. Biophys. Acta 134, 27 (1967)

9) Ueno, Y., Ueno, 1., Mizumoto, K. and Tatsuno, T.: J. Biochem. Tokyo 63, 395 (1968)

10) Uevo, Y., Ulino, I. and Mizurolo, K.: Japan. J. Exp. Med. 38, 47 (1968)

(1) Uevo, Y., UHNo, I., ITO, K. AND TATSuno, T.: Experientia 23, 1001 (1967)

12) UENo, Y. AND Ishikawa, I.: Appl. Microbiol. 18, 406 (1969)

13) LaYni, E.: Methods in Enzymology, Edited by Colowick, S.P. And Kaplan, N.O., Vol. 3, p 450, Academic Press, New York (1957)

14) Salto, M.: Acta pahl. Japom. 9, 785 (1959)

15) TAKagi, B.: Electron Vicroscopy 8, 154 (1959) (in Japanese)

16) Uino, I., Toklla, K., ITOI, Y. AND URAGUCHI, K.: Folia phamacol. japon, 65, 74\$ (1969) (in Japanese)

17) Unio, Y. avd UfNo, 1.: Folia pharmacol. japon. 60, 111 (1964) (in Japanese) 